\title{
Zasady rozpoznawania skaz krwotocznych ze szczególnym uwzględnieniem diagnostyki laboratoryjnej
}

\author{
Principles of diagnosis of bleeding disorders \\ with particular focus on laboratory diagnostics
}

\author{
Edyta Odnoczko ${ }^{1}$, Beata Baran ${ }^{1}$, Jerzy Windyga ${ }^{1,2}$ \\ ${ }^{1}$ Zakład Hemostazy i Chorób Metabolicznych, Instytut Hematologii i Transfuzjologii, Warszawa \\ ${ }^{2}$ Klinika Zaburzeń Hemostazy i Chorób Wewnętrznych, Instytut Hematologii i Transfuzjologii, Warszawa
}

\begin{abstract}
Streszczenie
Rozpoznawanie skaz krwotocznych jest procesem ztożonym, na który sktadaja sie precyzyjnie zebrany wywiady od chorego oraz od jego rodziny, skrupulatnie przeprowadzone badanie przedmiotowe oraz wtaściwy dobór $i$ wykonanie testów laboratoryjnych w celu ustalenia ostatecznego rozpoznania. $W$ niniejszym artykule przedstawiono obowiazujace zasady rozpoznawania skaz krwotocznych, ze zwróceniem bacznej uwagi na interpretacje wyników badań laboratoryjnych. W końcowej cześsi pracy zamieszczono algorytmy postepowania diagnostycznego integrujace wywiad krwotoczny pacjenta $z$ wynikami testów laboratoryjnych oceniajacych sprawność hemostazy.
\end{abstract}

Słowa kluczowe: hemostaza, wrodzone/nabyte skazy krwotoczne, testy laboratoryjne

Hematologia 2016; 7, 4: 303-311

\begin{abstract}
Recognising haemorrhagic disorders is a complex process which entails using an accurate personal medical or family history, meticulous physical examination and selecting the appropriate laboratory tests for making a final diagnosis. This paper describes currently applicable principles for diagnosis of bleeding disorders, specially emphasising how laboratory findings are interpreted. In the last part of the paper we present diagnostic algorithms that integrate the patient's history of bleeding with laboratory results regarding hemostasis.
\end{abstract}

Key words: hemostasis, inherited/acquired bleeding disorders, laboratory tests

Hematologia 2016; 7, 4: 303-311

\section{Wprowadzenie}

Samoistne krwawienie jest zawsze odchyleniem od stanu prawidłowego, a jedynym wyjątkiem od tej reguły pozostaje krwawienie miesiączkowe, o ile nie wiąże się $z$ nadmierną utratą krwi. Nawet po dużym urazie, prowadzącym do przerwania ciągłości łożyska naczyniowego, sprawne elementy hemostazy zapewniają zwykle szybkie zatrzymanie krwawienia. Oczywiście zdarzają się sytuacje, w których w pełni efektywna hemostaza nie jest w stanie zapobiec nadmiernemu wypływowi krwi. Tak dzieje się w przypadku uszkodzenia większych tętnic lub żył, na przykład wskutek zranienia chirurgicznego.

Ważnymi elementami procesu diagnostycznego w rozpoznawaniu zaburzeń hemostazy

Adres do korespondencji: Edyta Odnoczko, Zakład Hemostazy i Chorób Metabolicznych, Instytut Hematologii i Transfuzjologii, ul. Indiry Gandhi 14, 02-776 Warszawa, tel. 22349 65 48, faks 2234961 59, e-mail: eodnoczko@ihit.waw.pl 
Tabela 1. Wrodzone i nabyte skazy krwotoczne

Table 1. Inherited and acquired bleeding disorders

\begin{tabular}{|c|c|c|}
\hline Typ skazy krwotocznej & Choroba/stan kliniczny & Przykłady \\
\hline \multirow[t]{4}{*}{ Wrodzone } & $\begin{array}{l}\text { Dziedziczne niedobory } \\
\text { czynników krzepnięcia }\end{array}$ & $\begin{array}{l}\text { Hemofilia A (niedobór FVIII), hemofilia B (niedobór FIX), niedobór } \\
\text { czynników II, V, VII, X, XI, XIII, choroba von Willebranda, złożony } \\
\text { niedobór FV i FVIII, złożony niedobór czynników zespołu } \\
\text { protrombiny (II, VII, IX i X) }\end{array}$ \\
\hline & Trombocytopatie & Trombastenia Glanzmanna, zespół Bernarda-Souliera i in. \\
\hline & Skazy naczyniowe & $\begin{array}{l}\text { Wrodzona naczyniakowatość krwotoczna, zespół Ehlersa-Danlosa, } \\
\text { zespół Marfana i in. }\end{array}$ \\
\hline & Zaburzenia fibrynolizy & $\begin{array}{l}\text { Niedobór } \alpha_{2} \text {-antyplazminy, niedobór inhibitora aktywatora } \\
\text { plazminogenu typu } 1 \mathrm{i} \text { in. }\end{array}$ \\
\hline \multirow[t]{8}{*}{ Nabyte } & Małopłytkowości & $\begin{array}{l}\text { Auto- i alloimmunologiczne, hipersplenizm, polekowe, hipoplazja } \\
\text { szpiku, zespół rozsianego krzepnięcia wewnątrznaczyniowego }\end{array}$ \\
\hline & Choroby wątroby & Marskość, przeszczepienie wątroby, ostra niewydolność wątroby \\
\hline & $\begin{array}{l}\text { Zespół rozsianego } \\
\text { krzepnięcia } \\
\text { wewnątrznaczyniowego }\end{array}$ & $\begin{array}{l}\text { Ostry lub przewlekły, np. w przebiegu posocznicy, powikłań ciąży } \\
\text { i porodu, rozległych urazów }\end{array}$ \\
\hline & $\begin{array}{l}\text { W przebiegu chorób } \\
\text { hematologicznych }\end{array}$ & $\begin{array}{l}\text { Ostre białaczki, zespół mielodysplastyczny, nowotwory } \\
\text { mieloproliferacyjne, szpiczak plazmocytowy }\end{array}$ \\
\hline & Niedobór witaminy $\mathrm{K}$ & $\begin{array}{l}\text { Zespół złego wchłaniania, choroba krwotoczna noworodków, } \\
\text { przewlekła antybiotykoterapia, żółtaczka mechaniczna }\end{array}$ \\
\hline & Immunokoagulopatie & $\begin{array}{l}\text { Nabyta hemofilia A, nabyty zespół von Willebranda, inhibitory } \\
\text { wobec innych czynników krzepnięcia }\end{array}$ \\
\hline & Skazy naczyniowe & $\begin{array}{l}\text { Plamica Henocha-Schönleina, plamica starcza, plamica } \\
\text { posteroidowa i in. }\end{array}$ \\
\hline & Polekowe & $\begin{array}{l}\text { Leki przeciwpłytkowe, leki przeciwkrzepliwe, leki mielosupresyjne, } \\
\text { niesteroidowe leki przeciwzapalne }\end{array}$ \\
\hline
\end{tabular}

F (factor) - czynnik krzepnięcia

prowadzących do wystąpienia krwawień są: 1) wywiad od chorego, 2) wywiad rodzinny (wywiady te pozwalają wstępnie odróżnić chorobę wrodzoną od nabytej), 3) skrupulatne badanie przedmiotowe, 4) właściwy dobór badań laboratoryjnych w celu ustalenia prawidłowego rozpoznania.

W niniejszym artykule przedstawiono zasady rozpoznawania skaz krwotocznych, z uwzględnieniem charakterystycznych objawów podmiotowych i przedmiotowych oraz omówiono zasady interpretacji wyników testów laboratoryjnych wykorzystywanych w diagnostyce tej grupy chorób.

\section{Definicja i klasyfikacja skaz krwotocznych}

Mianem skazy krwotocznej określa się skłonność do nadmiernych krwawień wywołaną zaburzeniami w układzie hemostazy. Skazy krwotoczne można dzielić wedle różnych kryteriów [1]. Najczęściej podział dotyczy elementu hemostazy, którego funkcja uległa zaburzeniu. Wyróżnia się wówczas skazy krwotoczne naczyniowe, płytkowe (wynikające $z$ zaburzeń liczby płytek krwi lub $z$ upośledzenia ich funkcji), osoczowe (wynikające $z$ niedoborów czynników krzepnięcia), wywołane wzmożoną aktywnością fibrynolizy i złożone, w których więcej niż jeden element hemostazy jest upośledzony.

Innym kryterium podziału może być wrodzony lub nabyty charakter skazy krwotocznej (tab. 1). O ile wrodzone skazy krwotoczne są najczęściej powodowane pojedynczym defektem hemostazy, o tyle nabyte są zwykle wynikiem upośledzenia funkcji kilku elementów hemostazy.

\section{Objawy podmiotowe i przedmiotowe}

Występowanie od wczesnego dzieciństwa skłonności do nadmiernych krwawień powinno nasuwać podejrzenie wrodzonej skazy krwotocznej. Uwarunkowany genetycznie brak czynnika (F, factor) XIII i wrodzona afibrynogenemia objawiają się zaraz po urodzeniu krwawieniami z kikuta pępowiny. Dla braku FXIII patognomonicznym objawem jest samoistne krwawienie śródmózgowe [2]. Inne wrodzone skazy krwotoczne mają łagodniejszy przebieg i pierwsze objawy obserwuje się 
zwykle w późniejszym okresie życia. Podejrzenie dziedzicznej skazy krwotocznej staje się jeszcze bardziej zasadne, gdy u innych członków rodziny już wykryto skazę krwotoczną. Spośród wrodzonych skaz krwotocznych tylko hemofilie A i B dziedziczy się w sposób sprzężony z płcią (chorują mężczyźni, zaś kobiety są nosicielkami) [3]. Pozostałe wrodzone skazy krwotoczne dziedziczą się w sposób autosomalny, zatem kobiety chorują na nie tak samo często jak mężczyźni.

Wykrycie pewnych chorób może ukierunkować poszukiwanie określonej skazy krwotocznej. Na przykład angiodysplazja przewodu pokarmowego nierzadko wspólistnieje $z$ chorobą von Willebranda (vWD, von Willebrand disease) i prowadzi do częstych i ciężkich krwawień $z$ przewodu pokarmowego. U pacjentów $z$ wrodzoną skazą naczyniową wtórną do zaburzeń tkanki łącznej (zespół Ehlersa-Danlosa) obserwuje się bardzo charakterystyczne objawy — nadmiernie rozciągliwą skórę i skłonność do podwichnięć stawów. $Z$ kolei w przebiegu nowotworów mieloproliferacyjnych (nadpłytkowości samoistnej i czerwienicy prawdziwej) może się rozwinąć nabyty zespół von Willebranda, objawiający się między innymi intensywnymi krwawieniami śluzówkowymi.

Zabiegi inwazyjne, w tym ekstrakcje zębów oraz operacje chirurgiczne, są czułym testem sprawności układu hemostazy. O nadmiernym krwawieniu można mówić wtedy, gdy objętość utraconej krwi jest większa od przeciętnej objętości krwi traconej przez pacjentów poddawanych określonemu zabiegowi lub operacji. Obiektywnymi wskaźnikami utraconej krwi mogą być stężenia hemoglobiny sprzed i po operacji, liczba jednostek krwi przetoczonych w okresie okołooperacyjnym, objętość krwi ewakuowanej $z$ rany operacyjnej przez dreny. Nie można jednak zapominać, że najczęstszą przyczyną utrzymującego się krwawienia $z$ rany operacyjnej nie jest skaza krwotoczna, lecz brak miejscowej hemostazy, czyli skaleczone chirurgicznie naczynie krwionośne.

Przyczyną wystąpienia nadmiernych krwawień u pacjenta stosującego leki przeciwzakrzepowe może być ich przedawkowanie. Skłonność do krwawień może wystąpić u osoby stosującej leki przeciwzakrzepowe także wówczas, gdy wspólistnieje łagodna, uprzednio nierozpoznana, skaza krwotoczna, na przykład wrodzona trombocytopatia, która objawia się $z$ chwilą jatrogennego pogłębienia defektu hemostazy. Niesteroidowe leki przeciwzapalne upośledzają funkcję płytek krwi i mogą być przyczyną nadmiernych krwawień, zwłaszcza u pacjentów $z$ dodatkowymi, nawet niezbyt nasilonymi, defektami hemostazy, jak chociażby nieznaczna małopłytkowość. U pacjentów z podejrzeniem skazy krwotocznej należy unikać leków upośledzających hemostazę (np. kwasu acetylosalicylowego) oraz procedur inwazyjnych grożących powikłaniami krwotocznymi, w tym iniekcji domięśniowych.

Objawy skazy krwotocznej wynikającej z zaburzeń pierwotnej hemostazy (ściana naczyń i płytki krwi) różnią się od objawów skazy krwotocznej na tle zaburzeń hemostazy wtórnej (czynniki krzepnięcia i układ fibrynolizy) [3]. O ile defekt budowy ściany naczyń krwionośnych i liczby bądź funkcji płytek krwi prowadzą przede wszystkim do krwawień w obrębie błon śluzowych i skóry, o tyle niedobry czynników krzepnięcia krwi objawiają się formowaniem krwiaków w obrębie różnych narządów. Typowym objawem małopłytkowości są petocje na skórze kończyn dolnych i górnych oraz krwawienia $z$ nosa i dziąseł. $Z$ kolei charakterystycznym objawem ciężkich hemofilii A i B są samoistne krwawienia do stawów i mięśni. Nadmierne krwawienia miesiączkowe mogą wynikać zarówno z zaburzeń hemostazy pierwotnej, jak i wtórnej.

Pomocny w uporządkowaniu zbierania informacji na temat skłonności do krwawień jest punktowy kwestionariusz rekomendowany przez International Society on Thrombosis and Haemostasis (ISTH) (www.isth.org).

\section{Diagnostyka laboratoryjna skaz krwotocznych}

Ważnym aspektem rozpoznawania skaz krwotocznych jest właściwe postępowanie przedanalityczne, na które składają się czynności wykonywane przez personel medyczny przed przystąpieniem do analizy laboratoryjnej, a mianowicie: przygotowanie pacjenta do badań, pobranie próbek krwi, przygotowanie próbek osocza cytrynianowego i ich przechowywanie, transport materiału do laboratorium [4]. Warto podkreślić, $\dot{z}$ e etap przedanalityczny łączy się $z$ najwyższym ryzykiem wystąpienia błędu w całym procesie diagnostyki laboratoryjnej [5]. Dlatego poprawne wykonywanie czynności etapu przedanalitycznego warunkuje otrzymanie wiarygodnego wyniku badania laboratoryjnego.

\section{Testy laboratoryjne hemostazy pierwotnej}

Panel badań laboratoryjnych, wykorzystywanych do oceny sprawności hemostazy pierwotnej, obejmuje test globalny hemostazy pierwotnej, czyli pomiar czasu okluzji (CT, closure time) 
w analizatorze PFA-100 (lub PFA-200) (platelet function analyser, Siemens, Niemcy), a także testy swoiste - cytometryczną ocenę gęstości glikoprotein (GP, glicoprotein), błonowych płytek, badanie zdolności płytek do agregacji pod wpływem czynników agregujących (agonistów), określenie stężenia różnych białek wewnątrzpłytkowych i ich metabolitów oraz badania genetyczne [6]. Do podstawowych testów pierwotnej hemostazy zalicza się także automatyczny pomiar liczby i objętości płytek krwi (MPV, mean platelet volume), który rutynowo jest oznaczany $\mathrm{w}$ analizatorach hematologicznych.

Jeszcze kilka czy kilkanaście lat temu to pomiar czasu krwawienia (BT, bleeding time) był badaniem rutynowo wykorzystywanym do oceny hemostazy pierwotnej. Dziś w większości laboratoriów hemostazy pomiar CT w PFA-100/200 z powodzeniem zastąpił BT. Zasada testu PFA CT polega na tym, że w analizatorze PFA-100/200 pełna krew cytrynianowa jest pobierana pod wpływem podciśnienia przez kapilarę imitującą naczynie krwionośne o wysokim module ścinania (5000-6000/s). W jednorazowych kasetkach testowych płytki krwi napotykają na swej drodze membranę powleczoną kolagenem i epinefryną (Coll/EPI) lub kolagenem i difosforanem adenozyny (ADP, adenosine diphosphate) (Coll/ADP), w której znajduje się szczelina. Kontakt płytek krwi $z$ tymi agonistami sprawia, że za pośrednictwem czynnika von Willebranda (vWF, von Willebrand factor) dochodzi do adhezji płytek do kolagenu na membranie, w wyniku czego powstaje czop płytkowy zamykający światło szczeliny (okluzja). Czas potrzebny do zamknięcia otworu w membranie to CT, który stanowi wyrażany w sekundach wynik testu. Uzyskanie prawidłowego wyniku CT w teście Coll/EPI i Coll/ADP pozwala na wykluczenie ciężkiej postaci vWD, głębokiej małopłytkowości oraz ciężkich trombocytopatii [7]. Test PFA-100/200 cechuje jednak mała czułość w diagnostyce łagodnych zaburzeń hemostazy pierwotnej.

Testy agregacji płytek krwi zalicza się do swoistych testów hemostazy pierwotnej. Badanie to można przeprowadzić w osoczu bogatopłytkowym (PRP, platelet rich plasma) metodą agregometrii optycznej (LTA, light transmission aggregometry), uważanej za „złoty standard” w diagnostyce zaburzeń funkcji płytek krwi, bądź w krwi pełnej - metodą agregometrii impedancyjnej [8]. Istotą LTA jest pomiar zmian przepuszczalności (transmitancji) światła przechodzącego przez próbkę PRP podczas agregacji płytek indukowanej agonistami. Standardowy panel agonistów tworzą: ADP, epinefryna, kolagen typu I, kwas arachidonowy, rystocetyna. Zmierzona wartość transmitancji jest wyrażana w \% agregacji ( $\mathrm{w}$ odniesieniu do wyników agregacji prawidłowego PRP). Wartości referencyjne zwykle zawierają się $\mathrm{w}$ przedziale 60-90\%. Krzywa agregacji jest graficzną ilustracją tempa tworzenia i ,jakości” agregatów płytkowych. Do ograniczeń LTA należą: złożoność procedury wykonania, znaczna objętość krwi potrzebnej do wykonania badania (nawet $20-25 \mathrm{ml}$ ), konieczność przeprowadzenia oznaczenia w ciągu 4 godzin od pobrania krwi, wpływ licznych czynników przedanalitycznych i analitycznych, trudności w standaryzacji metody (co również wyklucza możliwość porównania wyników między laboratoriami). Interpretacja wyników testów agregacji płytek krwi może sprawiać wiele trudności, dlatego niezbędne jest doświadczenie osoby analizującej krzywe agregacyjne. Drugą metodą pozwalającą na ocenę funkcji płytek krwi jest agregometria impedancyjna prowadzona w próbce krwi pełnej. Zasadą tej metody jest przyleganie zaktywowanych agonistą płytek krwi do powierzchni elektrod, co prowadzi do wzrostu oporu elektrycznego (impedancji) między elektrodami w naczyniu pomiarowym. Do stymulacji krwinek płytkowych wykorzystuje się podstawowy panel czynników agregujących, choć w odmiennych stężeniach. Warto podkreślić, że odpowiedź płytek krwi na te związki w przypadku LTA i agregometrii impedancyjnej jest różna, zwłaszcza w obecności ADP i epinefryny. Wynik pomiaru wyrażony w omach $(\Omega)$ może być konwertowany na arbitralne jednostki agregacji. Ograniczeniami tej techniki są wpływ wartości hematokrytu, liczby płytek krwi, liczby leukocytów, zaś zaletami chociażby mniejsza objętość krwi potrzebnej do wykonania badania czy możliwość wykluczenia wpływu czynników związanych z przygotowaniem osocza. Jednak, mimo to, metoda impedancyjna jest rzadziej stosowana w laboratoriach hemostazy niż LTA. Obecnie w literaturze brakuje szerzej zakrojonych badań porównawczych LTA $z$ metodą impedancyjną oraz, tym bardziej, brakuje doświadczeń klinicznych opisujących ich przydatność $\mathrm{w}$ diagnostyce zaburzeń funkcji płytek krwi.

Cytometria przepływowa (FCM, flow cytometry) jest powszechnie znaną techniką umożliwiającą ocenę ekspresji (stężenia) GP powierzchniowych krwinek płytkowych. Badanie cytometryczne GP płytkowych wykonuje się u pacjentów $z$ odchyleniami w wynikach testów agregacji i/lub istotnym wywiadem klinicznym wskazującym na trombocytopatię. Dlatego FCM odgrywa ważną rolę $\mathrm{w}$ diagnostyce między innymi trombastenii 


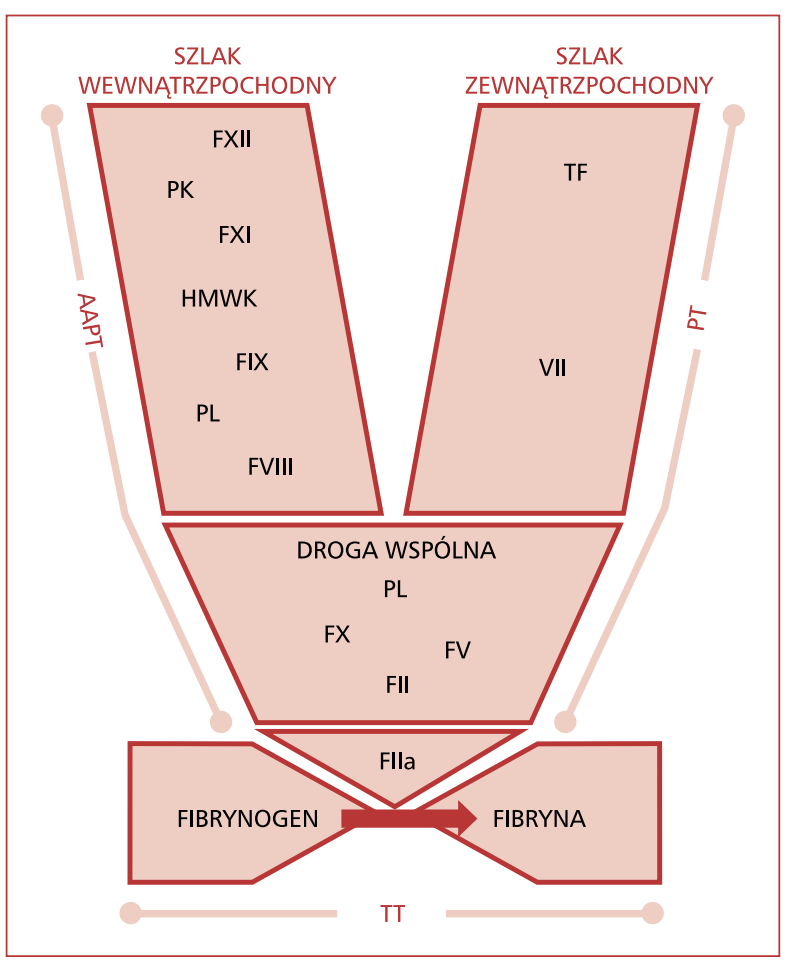

Rycina 1. Schemat kaskady krzepnięcia krwi i zasięg testów przesiewowych; APTT — czas częściowej tromboplastyny po aktywacji; F — czynnik krzepnięcia; PK — prekalikreina; HMWK — wielkocząsteczkowy kininogen; PL - fosfolipidy; TF — czynnik tkankowy; PT — czas protrombinowy; TT - czas trombinowy

Figure 1. Scheme of the blood coagulation cascade and scope of screening tests; APTT - activated partial thromboplastin time; F - factor; PK - prekallikrein; HMWK - high molecular weight kininogen; PL — phospholipids; TF — tissue factor; PT — prothrombin time; TT — thrombin time

Glanzmanna (niedobór lub brak GPIIb/IIIa) i zespołu Bernadarda-Souliera (deficyt GPIb/IX/V) [9].

Rozpoznanie niektórych bardzo rzadko występujących skaz płytkowych wymaga zastosowania wysokospecjalistycznych testów $[10,11]$. Na przykład w diagnostyce zaburzeń uwalniania substancji wewnątrzpłytkowych wykorzystuje się pomiar luminescencji w ocenie procesu wydzielania nukleotydów adeninowych (adenozytrifosforanu [ATP, adenosine triphosphate] i ADP), analizę ziarnistości gęstych w mikroskopie elektronowym, oznaczenia uwalniania serotoniny $z$ ziarnistości gęstych, oznaczenia stężenia markerów aktywacji płytek ( $\beta$-tromboglobuliny [ $\beta$-TG] lub czynnika płytkowego 4 [PF4, platelet factor 4]) w osoczu. Dodatkowo można badać produkty przemiany kwasu arachidonowego (oznaczając stężenie tromboksanu $\mathrm{B}_{2}$
$\left[\mathrm{TxB}_{2}\right.$, thromboxane $B_{2}$ ) w osoczu), metabolity tromboksanu (11-dehydro-TxB $\mathrm{B}_{2}$ ) bądź aktywność prokoagulacyjną płytek krwi (wykonując test dostępności fosfolipidów płytkowych) [12].

W celu potwierdzenia wrodzonego charakteru trombocytopatii sięga się po techniki biologii molekularnej, które umożliwiają wykrycie mutacji sprawczej. Wraz z postępem technik diagnostycznych coraz częściej wykonuje się badania genetyczne w diagnostyce trombastenii Glanzmanna i zespole Bernarda-Souliera, a także pseudo-vWD [13].

\section{Testy laboratoryjne hemostazy wtórnej}

Na panel badań służących ocenie wtórnej hemostazy składają się: 1) testy przesiewowe hemostazy, czyli pomiary czasów krzepnięcia osocza pod wpływem różnych aktywatorów i pomiar stężenia fibrynogenu oraz 2) testy swoiste hemostazy obejmujące między innymi oznaczanie aktywności i/lub zawartości czynników krzepnięcia, 3) testy do oceny sprawności fibrynolizy oraz 4) testy do oceny globalnego procesu krzepnięcia osocza lub pełnej krwi.

Testy przesiewowe krzepnięcia osoczowego

Czas częściowej tromboplastyny po aktywacji (APTT, activated partial thromboplastin time) definiuje się jako czas krzepnięcia osocza po maksymalnej aktywacji FXI i FXII. W tym teście do osocza ubogopłytkowego jest dodawany aktywator czynnika kontaktu oraz fosfolipidy. W kolejnym etapie mieszanina jest inkubowana przez $3-5$ minut $\mathrm{w}$ temperaturze $37^{\circ} \mathrm{C}$, a następnie dodaje się chlorek wapnia i mierzy czas do powstania włókien fibryny (wynik prawidłowy zwykle wynosi ok. $30 \mathrm{~s}$ ). Czas częściowej tromboplastyny po aktywacji służy do oceny sprawności tak zwanego wewnątrzpochodnego szlaku aktywacji krzepnięcia i drogi wspólnej (ryc. 1). Do przedłużenia APTT dochodzi w sytuacji niedoboru czynników XII, XI, IX, VIII oraz w mniejszym stopniu II, V, X i fibrynogenu. Największe wydłużenie APTT (wynik trzycyfrowy) obserwuje się w niedoborze czynników kontaktu - FXII, prekalikreiny oraz wielkocząsteczkowego kininogenu [14].

Czas protrombinowy (PT, prothrombin time) jest testem, w którym równe objętości osocza ubogopłytkowego i odczynnika zawierającego tromboplastynę tkankową (tj. czynnik tkankowy (TF, tissue factor) oraz chlorek wapnia są inkubowane przez minutę $\mathrm{w}$ temperaturze $37^{\circ} \mathrm{C}$. Wiążąc się z FVII, TF inicjuje proces krzepnięcia. Punktem końcowym pomiaru PT jest powstanie fibryny, 
co w tym układzie testowym zwykle zajmuje 8-15 s. $Z$ definicji PT jest zatem miarą zewnątrzpochodnego szlaku aktywacji protrombiny i drogi wspólnej. Wartość PT ulega wydłużeniu w niedoborze FVII i w porównaniu z APTT jest on bardziej czuły na niedobory czynników drogi wspólnej - II, V, X. Czas protrombinowy jest natomiast znacznie mniej wrażliwy od APTT na obecność heparyny w osoczu.

Czas trombinowy (TT, thrombin time) to test obrazujący reakcje zachodzące między trombiną i fibrynogenem, w którym do osocza ubogopłytkowego dodaje się trombinę, co powoduje bezpośrednie wykrzepianie fibrynogenu $z$ pominięciem aktywacji pozostałych czynników krzepnięcia. Prawidłowo do powstania skrzepu w tym układzie testowym dochodzi w czasie 16-21 s. Wynik TT jest wydłużony z powodu zmniejszonego stężenia lub zaburzonej struktury fibrynogenu, zwiększonego stężenia produktów degradacji fibrynogenu i/lub fibryny lub w obecności heparyny niefrakcjonowanej.

Czas reptylazowy (RT, reptilase time) to czas krzepnięcia osocza po aktywacji enzymem (reptylazą) uzyskanym z jadu węża Bothropsatrox (stąd inna nazwa tego testu - czas batroksobinowy). Reptylaza wykazuje podobną aktywność jak trombina, lecz w odróżnieniu od niej nie poddaje się działaniu heparyny i hirudyny. Prawidłowy wynik RT i przedłużony TT tej samej próbki osocza wskazują na obecność heparyny.

Test korekcji (test mieszania osocza) to badanie wykonywane w sytuacji uzyskania istotnie przedłużonego wyniku przesiewowego czasu krzepnięcia osocza pacjenta. Test ten jest bardzo przydatny w różnicowaniu przyczyn wydłużenia APTT lub PT, tj. niedoboru czynników krzepnięcia zależnego od obecności krążącego antykoagulantu [15, 16]. Polega on na wykonaniu ponownego pomiaru czasu krzepnięcia (APTT lub PT) w mieszaninie 1:1 osocza pacjenta $z$ osoczem prawidłowym, którą poddano godzinnej inkubacji w $37^{\circ} \mathrm{C}$. Uzyskanie korekcji, tj. istotnego skrócenia (niekiedy normalizacji) czasu krzepnięcia mieszaniny $\mathrm{w}$ porównaniu $\mathrm{z}$ czasem krzepnięcia osocza pacjenta, wskazuje na niedobór czynnika krzepnięcia. Natomiast brak korekcji (istotnego skrócenia) czasu krzepnięcia mieszaniny w porównaniu $z$ czasem krzepnięcia osocza pacjenta sugeruje obecność krążącego antykoagulantu. W rutynowej diagnostyce skaz krwotocznych najczęściej wykorzystuje się test korekcji APTT, który jest wykonywany w przypadku podejrzenia obecności inhibitora FVIII (wrodzona hemofilia A powikłana inhibitorem FVIII lub nabyta hemofilia A).

Stężenie fibrynogenu można mierzyć różnymi metodami laboratoryjnymi, między innymi nefelo- metryczną, immunoenzymatyczną, immunodyfuzji radialnej i kolorymetryczną; metoda oparta na pomiarze PT (ze względu na niską dokładność pomiarów) nie jest zalecana. Najczęściej jednak stosuje się metodę Claussa wykorzystującą pomiar TT, w której do rozcieńczonego osocza badanego dodaje się trombinę w wysokim stężeniu. Czas krzepnięcia tej mieszaniny jest odnoszony do krzywej kalibracyjnej i jest on odwrotnie proporcjonalny do stężenia fibrynogenu. Prawidłowe stężenie fibrynogenu zawiera się zwykle w przedziale 1,8$-4,5 \mathrm{~g} / \mathrm{l}$. Wzrost stężenia fibrynogenu obserwuje się w stanach zapalnych, chorobach nowotworowych, zespole nerczycowym, kolagenozach, ostrym zespole wieńcowym. Zmniejszone stężenie fibrynogenu występuje w hipo-, dys- oraz afibrynogenemii, w chorobach wątroby i w zespole rozsianego wykrzepiania wewnątrznaczyniowego.

\section{Testy swoiste hemostazy}

Aktywność czynników krzepnięcia w osoczu najczęściej oznacza się jednostopniową metodą koagulacyjną ( $z$ wykorzystaniem pomiaru PT lub APTT) $[17,18]$. Rozcieńczone osocze badane dodaje się do osocza substratowego (pozbawionego badanego czynnika krzepnięcia, ale zawierającego pozostałe składniki osocza), a krzepnięcie jest aktywowane odczynnikiem do PT (pomiar FII, FV, FVII, FX) lub APTT (pomiar FVIII, FIX, FXI, FXII) i chlorkiem wapnia. Ponieważ wszystkie czynniki krzepnięcia, $z$ wyjątkiem czynnika badanego, znajdują się $\mathrm{w}$ nadmiarze, mieszanina krzepnie z szybkością proporcjonalną do aktywności badanego czynnika. Uzyskany czas krzepnięcia jest odnoszony do krzywej kalibracyjnej, wyznaczonej wobec mianowanego osocza standardowego. Podobną, choć nieco bardziej skomplikowaną, metodą jest metoda koagulacyjna dwustopniowa, której, ze względu na złożoną procedurę i brak standaryzacji, nie stosuje się w rutynowej diagnostyce laboratoryjnej. $Z$ chwilą pojawienia się syntetycznych substratów chromogennych dwustopniową metodę koagulacyjną zastąpiono dokładniejszą i prostszą w wykonaniu metodą chromogenną. Metodą chromogenną można badać między innymi aktywność FVIII i FIX.

Do oznaczania stężenia (miana) przeciwciał skierowanych przeciwko czynnikowi krzepnięcia (tzw. inhibitora czynnika krzepnięcia) powszechnie jest stosowana metoda Bethesda. W tym przypadku jednakowe objętości osocza prawidłowego (źródło czynnika, wobec którego wykryto inhibitor) dodaje się do wielu próbek rozcieńczonego osocza pacjenta. Sporządzone mieszaniny są inkubowane przez 2 godziny w temperaturze $37^{\circ} \mathrm{C}$, po czym mierzy 
się w nich resztkową aktywność odpowiedniego czynnika krzepnięcia. Wynik testu Bethesda wyraża się w jednostkach Bethesda (BU, Bethesda units) $\mathrm{w}$ mililitrze $(\mathrm{BU} / \mathrm{ml})$, przy czym jedna jednostka oznacza taką ilość przeciwciał, która w opisanych warunkach neutralizuje 50\% aktywności danego czynnika krzepnięcia.

Do panelu testów swoistych wykorzystywanych w diagnostyce vWD należą badanie zawartości antygenu i aktywności vWF, ocena zdolności wiązania $v W F z$ kolagenem lub FVIII oraz badanie proporcji poszczególnych frakcji multimerów vWF $[19,20]$. Zawartość antygenu vWF (vWF:Ag, $v W F$ antigen) najczęściej oznacza się metodami immunologicznymi, w których stosuje się monospecyficzne przeciwciała skierowane przeciwko vWF tworzące kompleksy $z$ badanym białkiem. Wartości referencyjne vWF:Ag mieszczą się $\mathrm{w}$ przedziale 50 $-150 \mathrm{jm} . / \mathrm{dl}$. Badanie aktywności vWF polega na ocenie zdolności wiązania vWF z GPIba (GPIb). Interakcje vWF z GPIb najczęściej bada się w obecności rystocetyny, mierząc aktywność kofaktora rystocetyny (vWF:RCo, $v W F$ ristocetin cofactor activity). Wartości referencyjne mieszczą się w przedziale $50-150 \mathrm{jm} . / \mathrm{dl}$. Na podstawie wyników aktywności i zawartości vWF można obliczyć współczynnik vWF:RCo/vWF:Ag, który jest ważnym kryterium różnicowania vWD typu 1 i 2. Wartości tego współczynnika wynoszące powyżej 0,6 wskazują na typ 1 , a poniżej 0,6 - na typ 2 ( $z$ wyjątkiem podtypu $2 \mathrm{~N}$, w którym wartości są takie, jak w typie $1 \mathrm{vWD})$. Test wiązania vWF $z$ kolagenem ( $\mathrm{vWF}: \mathrm{CB}$, collagen binding assay) jest immunoenzymatycznym testem do oceny zdolności wiązania kolagenu przede wszystkim $z$ domeną A3 vWF. Czułość i swoistość testu vWF:CB zależy $\mathrm{w}$ dużej mierze od pochodzenia i typu zastosowanego kolagenu. Wynik badania może być przydatny w różnicowaniu podtypów typu 2 vWD. Wiązanie vWF z FVIII (vWF:FVIIIB, FVIII binding capacity of $v W F$ ) to test niezbędny do rozpoznania typu $2 \mathrm{NvWD}$ i odróżnienia tego podtypu vWD od hemofilii A. W teście vWF:FVIIIB określa się zdolność vWF do przyłączania egzogennego FVIII; wynik ponizej $20 \%$ potwierdza rozpoznanie vWD typu 2 N. Analiza multimerów vWF, to badanie dostarczające informacji o zawartości i dystrybucji multimerów vWF. Analiza polega na elektroforetycznym rozdziale frakcji vWF w żelu agarozowym lub poliakrylamidowym, immunoblottingu i ich detekcji. Wyniki analizy multimerów vWF pomagają zróżnicować podtypy typu $2 \mathrm{vWD}$. W podtypie $2 \mathrm{~A}$ obserwuje się niedobór dużych i pośrednich multimerów vWF, $\mathrm{w}$ podtypie $2 \mathrm{~B}$ - selektywny niedobór dużych multimerów, natomiast $\mathrm{w}$ podtypie $2 \mathrm{M}$ rozkład multimerów jest prawidłowy.

Badanie obecności czynnika XIII w osoczu zwykle rozpoczyna się przesiewowym testem jakościowym oceniającym rozpuszczalność skrzepu fibrynowego w roztworach o właściwościach kwasowych. Osocze pacjenta inkubowane jest $z$ chlorkiem wapnia lub mieszaniną trombiny, kaolinu i wapnia, co skutkuje wykrzepieniem fibrynogenu do fibryny. W celu stwierdzenia czy powstała fibryna jest stabilizowana FXIII (nierozpuszczalna) czy też niestabilizowana (rozpuszczalna), powstały skrzep przenosi się do $5 \mathrm{M}$ roztworu mocznika lub $1 \%$ kwasu monochlorooctowego [21]. W przypadku niedoboru FXIII skrzep rozpuszcza się w ciągu kilku minut, natomiast skrzep prawidłowego osocza pozostaje nierozpuszczony przez ponad 24 godziny. Testem specyficznym do badania aktywności FXIII w osoczu jest test ilościowy, w którym określa się aktywność FXIII jako transglutaminazy metodą chromogenną.

Ocena fibrynolizy jest największym wyzwaniem w diagnostyce laboratoryjnej zaburzeń hemostazy. Wyniki testów fibrynolizy, ze względu na wpływ licznych czynników interferujących, są trudne $\mathrm{w}$ interpretacji i mają niewielkie znaczenie kliniczne. Przykładem testu swoistego fibrynolizy jest czas lizy skrzepu euglobulin (ELT, euglobulin lysis time). Jest to mało czuły test przesiewowy, stanowiący miarę aktywności aktywatorów fibrynolizy. Wartości referencyjne wynoszą $2-5$ godzin. Alfa ${ }_{2}$-antyplazmina $\left(\alpha_{2}-\mathrm{AP}\right)$ jest inhibitorem wolnej plazminy, markerem aktywacji fibrynolizy, a jej niedobór może być przyczyną skłonności do krwawień. Aktywność tego inhibitora najczęściej oznacza się metodą chromogenną. Wartości referencyjne to 70-120\%.

Do globalnej oceny hemostazy wykorzystuje się: tromboelastografię/tromboelastometrię (TEG/ /TEM, thromboelastography/thromboelastometry) oraz test generacji trombiny (TGA, thrombin generation assay). Metody te umożliwiają graficzne rejestrowanie dynamiki procesów krzepnięcia i fibrynolizy oraz ocenę fizycznych właściwości utworzonego skrzepu. Badanie wykonuje się w pełnej krwi cytrynianowej po dodaniu jonów wapnia i/lub innych aktywatorów krzepnięcia. Obie metody wykorzystuje się głównie w ocenie złożonych zaburzeń hemostazy (np. w czasie zabiegów kardiochirurgicznych albo transplantacji wątroby). $Z$ kolei TGA to test polegający na monitorowaniu tempa i ilości wytwarzanej trombiny w badanej próbce osocza [22]. W pierwszym etapie tego badania do osocza dodaje się TF i fosfolipidy w celu aktywacji krzepnięcia. Powstała w badanym osoczu 


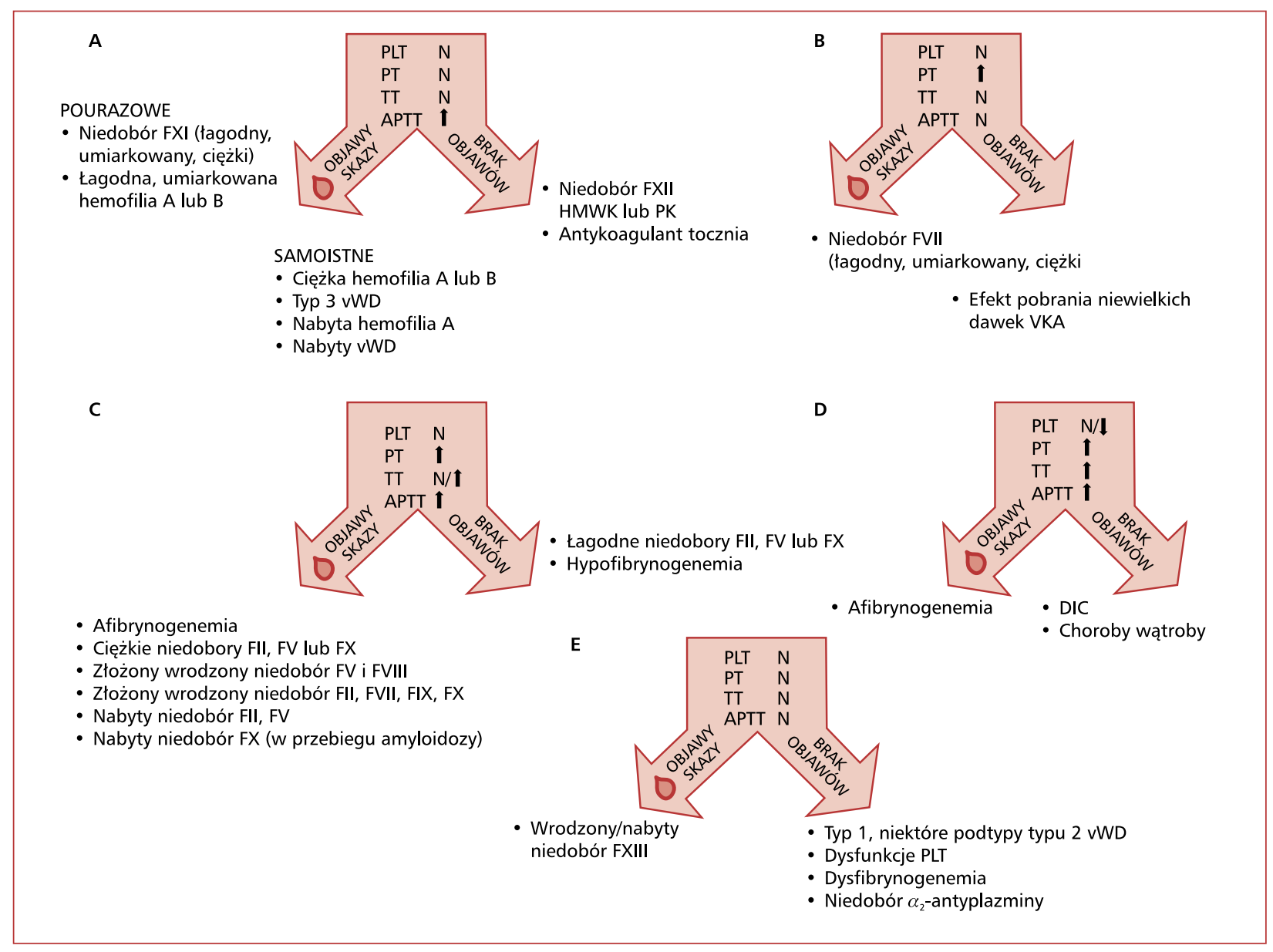

Rycina 2A-E. Algorytmy postępowania diagnostycznego integrujące wywiad krwotoczny pacjenta oraz wyniki testów przesiewowych hemostazy; F — czynnik krzepnięcia; PLT — płytki krwi; N — wynik prawidłowy; PT — czas protrombinowy; TT — czas trombinowy; APTT — czas częściowej tromboplastyny po aktywacji; HMWK — wielkocząsteczkowy kininogen; PK — prekalikreina; vWD — choroba von Willebranda; VKA — antagonista witaminy K; $\uparrow$ - wydłużony czas krzepnięcia; $\downarrow$ - zmniejszona liczba PLT; DIC — zespół rozsianego wykrzepiania wewnątrznaczyniowego

Figure 2A-E. Algorithms for diagnostic procedures that integrate patient hemorrhagic history with the results of screening tests for hemostasis; F — factor; PLT — platelets; N — normal; PT — prothrombin time; TT — thrombin time; APTT — activated partial thromboplastin time; HMWK — high molecular weight kininogen; PK — prekallikrein; VWD — von Willebrand disease; VKA — vitamin K antagonists; $\uparrow$ — prolonged clotting time; $\downarrow$ — decreased count of PLT; DIC — disseminated intravascular coagulation

trombina rozszczepia substrat fluorogenny, a zmiany fluorescencji rejestruje się w czasie rzeczywistym. Wynik TGA jest przedstawiony w postaci wykresu umożliwiającego obserwację stężenia trombiny w różnych fazach tworzenia się oraz lizy skrzepu. Obecnie test TGA wykorzystuje się głównie do celów naukowych.

\section{Podsumowanie}

Rozpoznawanie skaz krwotocznych jest złożonym procesem. Na rycinie 2 przedstawiono algo- rytmy postępowania diagnostycznego integrujące wywiad krwotoczny pacjenta $z$ wynikami testów przesiewowych hemostazy.

\section{Piśmiennictwo}

1. Selighson U., Coller B.S. Classification, clinical manifestations and evaluation of disorders of hemostasis. W: Williams hematology. $6^{\text {th }}$ edition. McGraw-Hill, New York 2000: 1471-1477.

2. Nugent D., Hsieh L. Factor XIII deficiency. W: Christine A. Lee C.A, Berntorp E.E., Hoots K.W. (red). Textbook of hemophilia. $3^{\text {th }}$ edition. Wiley-Blackwell, Oxford 2014: 436-444.

3. Windyga J., Chojnowski K., Klukowska A. i wsp. Część I: Wytyczne postępowania w hemofilii A i B niepowikłanej inhibitorem 
czynnika VIII i IX (wydanie zaktualizowane). Acta Hematol. Pol. 2016; 47: 86-114.

4. Lippi G., Salvagno G.L., Montagnana M. i wsp. Quality standards for sample collection in coagulation testing. Semin. Thromb. Hemost. 2012; 38: 565-575.

5. Adcock Funk D.M. Sample integrity and preanalytical variables. W: Kitchen S., Olson J.D., Preston F.E. (red.). Quality in laboratory hemostasis and thrombosis. Second edition. Wiley-Blackwell, Oxford 2009: 45-56.

6. Harrison P., Mackie I., Mumford A. i wsp. Guidelines for the laboratory investigation of heritable disorders of platelet function. Br. J. Haematol. 2011; 155: 30-44.

7. Favaloro E.J. Clinical utility of the PFA-100. Semin. Thromb. Hemost. 2008; 34: 709-733.

8. Cattaneo M., Cerletti C., Harrison P. i wsp. Recommendations for the standardization of light transmission aggregometry: a consensus of the Working Party from the Platelet Physiology Subcommittee of SSC/ISTH. J. Thromb. Haemost. 2013; Apr 10. doi: 10.1111/jth.12231 [Epub ahead of print].

9. Carubbi C., Masselli E., Gesi M. i wsp. Cytofluorimetric platelet analysis. Semin. Thromb. Hemost. 2014; 40: 88-98.

10. Chojnowski K., Klukowska A., Łętowska M. i wsp. Część III: Zasady postępowania we wrodzonych zaburzeniach czynności płytek krwi. Acta Haematol. Pol. 2009; 40: 731-752.

11. Chojnowski K. Płytkowe skazy krwotoczne wrodzone i nabyte. W: Dmoszyńska A. (red). Wielka Interna. Hematologia. Wyd. Medical Tribune Polska, Warszawa 2011: 643-664.

12. Gresele P. Subcommittee on Platelet Physiology of the International Society on Thrombosis and Hemostasis. Diagnosis of inherited platelet function disorders: guidance from the SSC of the ISTH. J. Thromb. Haemost. 2015; 13: 314-322.

13. Gresele P., Bury L., Falcinelli E. Inherited platelet function disorders: algorithms for phenotypic and genetic investigation. Semin. Thromb. Hemost. 2016; 42: 292-305.

14. Chojnowski K., Podolak-Dawidziak M., Windyga J. Diagnostyka przedłużonego czasu częściowej tromboplastyny po aktywacji (aPTT). Hematologia 2010; 1: 81-86.

15. McCraw A., Hillarp A., Echenagucia M. Considerations in the laboratory assessment of haemostasis. Haemophilia 2010; 16: 74-78.

16. Bolton-Maggs P.H.B., Favaloro E.J., Hillarp A. i wsp. Difficulties and pitfalls in the laboratory diagnosis of bleeding disorders. Haemophilia 2012; 18: 66-72.

17. Chitlur M. Challenges in the laboratory analyses of bleeding disorders. Thromb. Res. 2012; 130: 1-6.

18. Mackie I., Cooper P., Lawrie A. i wsp. Guidelines on the laboratory aspects of assays used in haemostasis and thrombosis. Int. J. Lab. Hem. 2013; 35: 1-13.

19. Flood V.H. Perils, problems, and progress in laboratory diagnosis of von Willebrand disease. Semin. Thromb. Hemost. 2014; 40: 41-48.

20. Favaloro E.J. Laboratory evaluation of von Willebrand disease: phenotypic analysis. W: Kitchen S., Olson J.D., Preston F.E. (red.). Quality in laboratory hemostasis and thrombosis. Second edition. Wiley-Blackwell, Oxford 2014: 192-203.

21. Mariańska B., Fabijańska-Mitek J., Windyga J. Zaburzenia krzepnięcia krwi. Badania laboratoryjne w hematologii. PZWL, Warszawa 2003: 166-191.

22. Kitchen S., Hayward C., Negrier C. i wsp. New developments in laboratory diagnosis and monitoring. Haemophilia 2010; 16: 61-66. 